\title{
Estimation of Genetic Parameters for Live Weight in South African Holstein Cattle
}

\author{
Nokuthula Innocentia Ramatsoma1,2*, Cuthbert Baldwin Banga², \\ Khoboso Christina Lehloenya ${ }^{3}$, Rory Gibson ${ }^{1}$ \\ ${ }^{1}$ Department of Animal Sciences, Tshwane University of Technology, Pretoria, South Africa \\ ${ }^{2}$ Agricultural Research Council, Animal Production Institute, Irene, South Africa \\ ${ }^{3}$ Department of Animal and Wildlife Sciences, University of Pretoria, Pretoria, South Africa \\ Email: "Ramatsoma@arc.agric.za
}

Received 26 March 2015; accepted 31 May 2015; published 4 June 2015

Copyright (C) 2015 by authors and Scientific Research Publishing Inc.

This work is licensed under the Creative Commons Attribution International License (CC BY). http://creativecommons.org/licenses/by/4.0/

\section{(c) (i) Open Access}

\begin{abstract}
Cow live weight is of economic importance in dairy production; however, it is not included in the selection objective for South African dairy cattle. Variance components estimates are a prerequisite to incorporating a trait in the breeding objective. Variance components were estimated for live weight of lactating Holstein cows on two South African dairy herds. Live weight records on 9843 lactating cows, collected over a period of three years, were used. An analysis of variance was carried out to determine fixed effects to include in the model by the least squares method, using the Generalised Linear Models procedure of the Statistical Analysis System. Variance components were estimated by the Restricted Maximum Likelihood procedure using the ASREML programme. A high heritability estimate of $0.74 \pm 0.19$ is found, which suggests that there is scope for significant response to selection on live weight in the South African Holstein cattle population. A repeatability estimate of 0.86 was obtained. These results form the basis for incorporating live weight in the breeding objective for South African Holstein cattle. Further work, however, needs to be done to develop estimates based on a representative sample of the whole population, as the current study is based on data from only two herds.
\end{abstract}

\section{Keywords}

Live Weight, Breeding Objective, Variance Components, Heritability, Dairy Cows

\footnotetext{
${ }^{*}$ Corresponding author.
}

How to cite this paper: Ramatsoma, N.I., Banga, C.B., Lehloenya, K.C. and Gibson, R. (2015) Estimation of Genetic Parameters for Live Weight in South African Holstein Cattle. Open Journal of Animal Sciences, 5, 242-248. 


\section{Introduction}

The Holstein is the most popular dairy cattle breed in South Africa. Presently, about 53,151 Holstein cows are participating in the South African National Milk Recording Scheme [1]. The average milk production of these cows per 305 day lactation is $7441 \mathrm{~kg}$ compared to Ayrshire, Guernsey and Jersey which produce $6072 \mathrm{~kg}, 5570$ $\mathrm{kg}$ and $5187 \mathrm{~kg}$ respectively [1].

Continued decline in dairy herd profitability poses a serious challenge to the South African dairy industry. Due to this problem, the number of milk producers in South Africa has declined from 3899 in January 2007 to 2083 in September 2013 [2]. There is, therefore, a pressing need to improve the profitability of milk production in South African dairy herds. In order to achieve such improvement, from a genetic improvement perspective, all economically important traits should be included in the selection objective. Live weight is among the traits of economic importance in dairy production, as it affects dairy herd profitability through its effect on cow maintenance costs and income from beef (culled cows). Cows with increased live weight tend to have higher maintenance requirements, which are not compensated for by higher revenue from the sale of beef (culled cows), resulting in negative economic value [3]-[5]. In South African dairy cattle, a kilogram increase in live weight was recently reported to result in a decrease in profit of up to ZAR 7.49 [6]. In the past, little or no emphasis was placed on non-production traits, such as live weight, in most breeding objectives worldwide [7]. In South Africa, genetic trends show that dairy cattle have been selected mainly for increased yield and improved type [8] [9]. Such narrow breeding objectives hamper improvement in total economic merit. In recent years, there has been a shift towards more balanced, profit-focused breeding objectives, globally, by including all economically relevant traits [7].

The aim of this study was to estimate genetic parameters for live weight in South African Holstein cattle. Such parameters are a prerequisite to incorporating live weight into the selection objective of South African Holstein cattle.

\section{Materials and Methods}

Two herds that routinely record live weight data were identified by South African National Milk Recording Scheme technicians. The first herd was Groenpunt Correctional Services Dairy Farm, situated in Vereeniging, Gauteng Province, which has an average of 55 lactating cows. The second herd was Elsenburg Experimental Station, Western Cape Department of Agriculture, which is situated in Elsenburg, Western Cape Province with an average of 162 lactating cows. Only live weights of lactating Holstein cows were used. Cows were weighed daily after the morning milking using weighing scales approved by the National Livestock Improvement Scheme. Cows at Groenpunt Correctional Services Dairy Farm were fed $32 \mathrm{~kg}$ of a total mixed ration per cow per day.The diet consisted of lucerne hay, yellow maize, silage, brewers grain, weeping love grass and salt. After milking, cows are provided an average of $9 \mathrm{~kg}$ of dairy meal per cow per day depending on production. Moreover due to different production stages cows are housed separately in sheds.

The feeding program and management for Elsenburg Experimental Station was as described by [10]. Live weight data were merged with milk production and pedigree data from the Integrated Registration and Genetics Information System of South Africa (Intergis). Live weights collected between 1 and 305 days of lactation were selected. Cows were aged between 24 and 96 months and ranged from lactation 1 to 8. Data editing was carried out using the Statistical Analysis System software [11]. The original data set consisted of 29,079 live weight records of 195 cows. Herd-year-season of weighing (HYS) was defined as the contemporary group. Data were edited to remove records without live weight, birth date, calving date or identification number. After editing, the remaining data set had 9843 live weight records on 94 cows.

\subsection{Environmental Factors Affecting Live Weight}

An analysis of variance (ANOVA) was conducted to determine environmental factors affecting live weight; such effects need to be fitted in the model for variance component estimation. The General Linear Models (GLM) procedure of the Statistical Analysis System software [11] was used and the following environmental factors were tested for:

- Herd-year-season of weighing;

- Parity;

- Age at weighing;

- Days in milk at weighing; 
- Quadratic effects for days in milk;

- Two way interactions between all the above effects.

\subsection{Estimation of Variance Components for Live Weight}

Variance components for live weight were estimated by the Restricted Maximum Likelihood (REML) procedure, using the ASREML programme [12]. The following single trait repeatability animal model was used:

$$
y=X b+Z u+W_{p e}+e
$$

where:

$y=$ vector of observations of live weight;

$X=$ incidence matrix relating fixed effects to observations;

$b=$ vector of fixed effects influencing live weight;

$Z$ = incidence matrix relating random animal additive genetic effects to observations;

$u=$ vector of animal additive genetic effects;

$W=$ incidence matrix relating random permanent environmental effects to observations;

$p e=$ vector of permanent environmental effects, to account for effects influencing the repeated live weight records;

$e=$ is the vector of random residual effects.

Random animal additive genetic effects ( $a$ ) were assumed to have the distribution $N \sim\left(0, A \sigma_{a}^{2}\right)$, where $A$ is the additive genetic relationship matrix and $\sigma_{a}^{2}$ is the animal additive genetic variance. Residual effects $e$ were assumed to be normally, independently and identically distributed with mean 0 and variance $\sigma_{e}^{2}$ (i.e.

$e \sim N\left(0, I \sigma_{e}^{2}\right)$, and $\operatorname{cov}(a, e)=0$. Permanent environmental effects were assumed to be distributed with $N \sim\left(0, I \sigma_{p e}^{2}\right)$, where I is an identity matrix, $\sigma_{p e}^{2}$ is the variance due to permanent environmental effects and $\operatorname{cov}(p e, e)=0$ and $\operatorname{cov}(a, p e)=0$.

Thus, the (co)variance structure of the random effects was assumed to be as follows:

$$
\left[\begin{array}{c}
a \\
p e \\
e
\end{array}\right]=\left[\begin{array}{ccc}
A \sigma_{a}^{2} & 0 & 0 \\
0 & I \sigma_{p e}^{2} & 0 \\
0 & 0 & I \sigma_{e}^{2}
\end{array}\right]
$$

\subsection{Calculation of Phenotypic Variance, Heritability and Repeatability}

The phenotypic variance of live weight $\left(\sigma_{p}^{2}\right)$ was calculated as the sum of additive genetic variance $\left(\sigma_{a}^{2}\right)$, permanent environmental variance $\left(\sigma_{p e}^{2}\right)$ and residual variance $\left(\sigma_{e}^{2}\right)$ (Falconer \& Mackay, 1996) :

$$
\sigma_{p}^{2}=\sigma_{a}^{2}+\sigma_{p e}^{2}+\sigma_{e}^{2}
$$

The heritability of live weight $\left(h^{2}\right)$ was calculated as the ratio of animal additive genetic variance to phenotypic variance (Falconer \& Mackay, 1996):

$$
h^{2}=\frac{\sigma_{a}^{2}}{\sigma_{p}^{2}}
$$

The repeatability of live weight ( $r$ ) was calculated as the sum of additive genetic variance and permanent environmental variance to the phenotypic variance (Falconer \& Mackay, 1996):

$$
r=\frac{\sigma_{a}^{2}+\sigma_{p e}^{2}}{\sigma_{p}^{2}}
$$

\section{Results and Discussion}

An overall mean of $570 \pm 0.80 \mathrm{~kg}$ (Table 1) was obtained for live weight across parities. The same mean was obtained for Holstein cattle in Ireland [13]. Another study in Ireland [14] reported a higher mean for pre-calving Holstein cows. Higher means of $587 \mathrm{~kg}$ at parturition and $641 \mathrm{~kg}$ in third parity, respectively, were also found in United States Holstein cattle [15] [16]. Danish Friesian cattle were also heavier at $593 \mathrm{~kg}$ [17]. Using data from 
Table 1. Summary of the descriptive statistics.

\begin{tabular}{cccccc}
\hline Number of records & Minimum $(\mathrm{kg})$ & $\begin{array}{c}\text { Maximum } \\
(\mathrm{kg})\end{array}$ & Mean \pm standard error $(\mathrm{kg})$ & $\begin{array}{c}\text { standard } \\
\text { deviation }(\mathrm{kg})\end{array}$ & Coefficient of variation (\%) \\
\hline 9843 & 374 & 730 & $570 \pm 0.80$ & 79 & 14 \\
\hline
\end{tabular}

Elsenburg Experimental Farm, one of the herds used in the current study, but from earlier years, [10] obtained a lower mean of $533 \mathrm{~kg}$. The current study analysed data on eight parities, whereas [10] only focused on the first three parities. The higher mean live weight for the current study may partly be due to a correlated increase in live weight with increase in yield traits in this herd, over time. There has been a positive genetic trend in yield traits in recent years in the herd [18] and a high positive correlation is known to exist between live weight and yield traits in dairy cattle [10]. A high positive correlation is known to exist between live weight and yield traits in dairy cattle [10].

Studies conducted in New Zealand and the Netherlands reported lower mean live weights of $404 \mathrm{~kg}$ and 520 kg, respectively [19] [20] in Friesian cattle. The low live weight for New Zealand Friesians is probably due to sustained negative selection on live weight. New Zealand is one of the few countries that include live weight, with negative emphasis, in the selection objective [21].

\subsection{Environmental Factors Influencing Live Weight}

Environmental effects significantly affecting live weight $(\mathrm{P}<0.001)$ were herd-year-season of weighing, parity, age at weighing, days in milk and quadratic effects of days in milk as illustrated in Table 2. Several other studies [10] [13] [17] [19] [22] [23] have also reported parity to be a significant source of variation in live weight.

Herd-year-season of weighing corrects for the effects associated with yearly and seasonal climatic variation and management differences among herds [24]. Age at weighing also had a significant effect $(\mathrm{P}<0.001)$ on live weight in a study on Holstein cows in Finland [22]. Alawneh [19] also observed a significant effect $(P<0.05)$ of days in milk on individual live weights record between 0 - 100 days of lactation.

\subsection{Variance Component Estimates}

Estimating variance components for live weight in the South African Holstein cattle population forms part of an objective for this study. Such estimates are a prerequisite to incorporating live weight into the selection objective of South African Holstein cattle. Estimates of variance components, heritability and repeatability for live weight are presented in Table 3 . Live weight had high heritability (0.74) and repeatability (0.86) estimates. The high repeatability indicates a high influence of permanent environmental effects on repeated measures of live weight in South African Holstein cattle. Toshniwal et al. [25] obtained a slightly lower repeatability of 0.76 in United States Holstein cows.

The heritability was similar to estimates reported in Norway and the Netherlands, which ranged between 0.71 and 0.88 [26] [27]. Such a high estimate of heritability implies that there is scope for significant response to selection on live weight in the South African Holstein cattle population. Veerkamp et al. [28], Berry et al. [29] and Muller et al. [10] found moderate heritabilities (0.60 - 0.61) in South African, Irish and Netherlands Holstein cows, respectively. Fairly lower heritability estimates, between 0.40 and 0.50 , were reported by [23] [25] [30] [31]. Distinctly lower heritabilities of 0.24 - 0.36 were found in other studies [15] [32]-[34]. Differences in heritability estimates among studies may, in part, be due to the variation in stages at which live weight was measured. For example, [28] used live weights in parity 1 and [10] used live weights measured in lactations 1 to 3. Veerkamp and Brotherstone [30] measured live weight at 26 weeks of lactation. Toshniwal et al. [25] measured daily live weight at 1 - 26 weeks and [31] predicted live weight from type traits at 29 - 33 weeks of lactation. Heritability is also a parameter that varies from one population to another.

\section{Conclusion}

Results of this study may assist in including live weight in the selection objective for South African Holstein cattle. Herd-year-season of weighing, parity, age at weighing, days in milk and quadratic effects for days in milk significantly influence live weight in the two South African herds used in the current study. These factors should, therefore, be accounted for when analysing live weight data. The high estimate of heritability of live weight 
Table 2. Environmental factors influencing live weight in South African Holstein cattle.

\begin{tabular}{|c|c|c|}
\hline Factor & least squares means & Level significance \\
\hline Parity & 5296434.17 & * \\
\hline HYS & 119079.05 & $*$ \\
\hline DIM & 2160141.56 & $*$ \\
\hline $\mathrm{DIM}^{2}$ & 39052.71 & * \\
\hline Age & 126285.12 & $*$ \\
\hline Interaction between DIM and Parity & 93293.14 & * \\
\hline Interaction between DIM and Age & 20452.151 & NS \\
\hline Interaction between Age and Parity & 7119.536 & NS \\
\hline Interaction between DIM and HYS & 8766.369 & NS \\
\hline $\mathrm{Age}^{2}$ & 4068.379 & NS \\
\hline
\end{tabular}

*Significant $(\mathrm{p}<0.001)$; NS, Not significant.

Table 3. Variance components, heritability \& repeatability of live weight.

\begin{tabular}{cccccc}
\hline$\sigma_{\mathrm{a}}^{2}$ & $\sigma_{p e}^{2}$ & $\sigma_{e}^{2}$ & $\sigma_{p}^{2}$ & $r$ & $h^{2} \pm s . e$ \\
\hline 3285 & 501 & 634 & 4420 & 0.86 & $0.74 \pm 0.19$ \\
\hline
\end{tabular}

$h^{2}=$ Heritability; $\sigma_{\mathrm{a}}^{2}=$ Additive genetic variance; $\sigma_{p e}^{2}=$ permanent environmental variance; $\sigma_{p}^{2}=$ phenotypic variance; $r=$ repeatability;

$\sigma_{e}^{2}=$ residual (error) variance; $\mathrm{SE}=$ standard error.

obtained in the present study indicates that there is potential for significant rate of genetic change if selection is applied on live weight in this population. Variance components, on which this heritability estimate is based, can be used to calculate estimated breeding values for live weight; thus making it possible to include live weight in the breeding objective for South African Holstein cattle. It should be noted, however, that these estimates are based on only two herds and therefore are not representative of the whole population. There is therefore a need to build on the results of this study by collecting and analysing live weight from a much larger proportion of South African Holstein herds.

\section{Acknowledgements}

The authors would like to acknowledge the Agricultural Research Council and National Research Foundation for providing financial support to this study. We wish to thankDr CJC Muller (Elsenburg Experimental Station) and staff at Groenpunt Correctional Services Dairy Farm for kindly providing us with the live weight records and other relevant information.

\section{References}

[1] National Milk Recording and Improvement Scheme (2012) Agricultural Research Council. Annual Report, $2011-2012$.

[2] Lacto Data (2013) 162. http://www.milksa.co.za/sites/default/files/BIPLAC017\%20LACTO\%20DATA\%20November\%202013.pdf

[3] Dempfle, L. (1986) Increasing the Efficiency of the Dairy Cow with Regard to Body Size. Livestock Improvement Company, New Zealand Dairy Board, Hamilton, Research Bulletin, 4.

[4] Visscher, P.M., Bowman, P.J. and Goddard, M.E. (1994) Breeding Objectives for Pasture Based Dairy Production Systems. Livestock Production Science, 40, 123-137. http://dx.doi.org/10.1016/0301-6226(94)90042-6

[5] Groen, A.F., Arendonk, J.A.M., Van Steverink, M.H.A. and Berentsen, P.B.M. (1994) The Economic Value of Body Weight in Dairy Cattle Influences of Farm Intensity and Environmental Legislation. Proceedings of the Forth-Fifth Annual Meeting of the European Association of Animal Production, Edinburg.

[6] Banga, C.B., Neser, F.W.C., Van der Westhuizen, J. and Garrick, D.J. (2010) Economic Value of Live Weight in South African Dairy Cattle. Proceedings of the Tenth World Congress on Genetics Applied to Livestock Production, Leipzig. 
[7] Miglior, F., Muir, B.L. and Van Doormaal, B.J. (2005) Selection Indices in Holstein Cattle of Various Countries. Journal of Dairy Science, 88, 1255-1263. http://dx.doi.org/10.3168/jds.S0022-0302(05)72792-2

[8] Theron, H.E. and Mostert, B.E. (2004) Genetic Analyses for Conformation Traits in South African Jersey and Holstein Cattle. South African Journal of Animal Science, 34, 47-49. http://dx.doi.org/10.4314/sajas.v34i6.3828

[9] Banga, C.B., Mostert, B.E., Makgahlela, M.L., Theron, H.E. and Van Der Westhuizen, J. (2007) Impact of Advances in Animal Recording and Genetic Evaluation Technologies on Dairy Herd Performance in South Africa. Proceedings of the South African Society of Animal Science Congress, Bella.

[10] Muller, C.J.C., Cloete, S.W.P., Olivier, J.J., Botha, J.A. and De Waal, H. (2006) Heritability of Live Weight and Condition Score in a Holstein Herd and Correlations with Milk Traits-Preliminary Estimates. Journal of Animal Science, 36, 79-88.

[11] SAS (2012) Statistical Analysis Systems. SAS User Guide: Release 9.3. Statistical Analysis System Institute, Inc., Cary.

[12] Gilmour, A.R., Gogel, B.J., Cullis, B.R., Welham, S.J. and Thompson, R. (2002) ASReml User Guide Release 1.0. VSN International Ltd., Hemel Hempstead.

[13] Walsh, S., Buckley, F., Pierce, K., Byrne, N., Patton, J. and Dillon, P. (2008) Effects of Breed and Feeding System on Milk Production, Body Weight, Body Condition Score, Reproductive Performance, and Postpartum Ovarian Function. Journal of Dairy Science, 91, 4401-4413. http://dx.doi.org/10.3168/jds.2007-0818

[14] Buckley, F., O’sullivan, K., Mee, J.F., Evans, R.D. and Dillon, P. (2003) Relationships among Milk Yield, Body Condition, Cow Weight, and Reproduction in Spring-Calved Holstein-Friesians. Journal of Dairy Science, 86, 2308-2319. http://dx.doi.org/10.3168/jds.S0022-0302(03)73823-5

[15] Badinga, I., Collier, R.J., Wilcox, C.J. and Thatcher, W.W. (1985) Interrelationships of Milk Yield, Body Weight and Reproduction Performance. Journal of Dairy Science, 68, 1828-1832. http://dx.doi.org/10.3168/jds.S0022-0302(85)81034-1

[16] Hansen, L.B., Cole, J.B., Marx, G.D. and Seykora, A.J. (1998) Production Life and Reasons for Disposal of Holstein Cows Selected for Large versus Small Body Size. Journal of Animal Science, 87, 795-801.

[17] Enevoldsen, C. and Kristensen, T. (1997) Estimation of Body Weight from Body Size Measurements and Body Condition Scores in Dairy Cows. Journal of Animal Science, 80, 1988-1995. http://dx.doi.org/10.3168/jds.s0022-0302(97)76142-3

[18] Muller, C.J.C. (2014) Personal Communication.

[19] Alawneh, I.J. (2011) Monitoring Live Weight to Optimise Health and Productivity in Pasture Fed Dairy Herds. Ph.D. Dissertation, Massey University, Palmerston.

[20] Veerkamp, R.F. and Thomps, S. (1999) A Covariance Function for Feed Intake Live Weight and Milk Yield Estimated Using a Random Regression Model. Journal of Animal Science, 82, 1565-1573. http://dx.doi.org/10.3168/jds.s0022-0302(99)75384-1

[21] Holmes, C.W., Brookes, I.M., Garrick, D.J., Mackenzie, D.D.S., Parkinson, T.J. and Wilson, G.F. (2000) Milk Production from Pasture. Massey University, Palmerston.

[22] Hietanen, H. and Ojala, M. (1995) Factors Affecting Body Weight and Its Association with Milk Production Traits in Finnish Ayrshire and Friesian Cows. Acta Agriculturae Scandinavica, Section A-Animal Science, 45, 17-25. http://dx.doi.org/10.1080/09064709509410909

[23] McHugh, N., Evans, R.D., Amer, P. R., Fahey, A.G. and Berry, D.P. (2011) Genetic Parameters for Cattle Price and Body Weight from Routinely Collected Data at Livestock Auctions and Commercial Farms. Journal of Animal Science, 89, 29-39. http://dx.doi.org/10.2527/jas.2010-3044

[24] Nilforooshan, M.A. (2010) Contemporary Grouping in Mixed-Size Dairy Herds Experiencing Four Seasons. Journal of Veterinary Animal Science, 34, 129-135.

[25] Toshniwal, J.K., Dechow, C.D., Cassell, B.G., Appuhamy, J.A. and Varga, G.A. (2008) Heritability of Electronically Recorded Daily Body Weight and Correlations with Yield, Dry Matter Intake, and Body Condition Score. Journal of Dairy Science, 91, 3201-3210. http://dx.doi.org/10.3168/jds.2007-0627

[26] Van Arendonk, J.A.M., Hovenier, R. and Willem, D.B. (1991) Phenotypic and Genetic Association between Fertility and Reproduction in Dairy Cows. Livestock Production Science, 21, 1-12. http://dx.doi.org/10.1016/0301-6226(89)90017-1

[27] Svendsen, M., Skipenes, P. and Mao, I.L. (1994) Genetic Correlations in the Feed Conversion Complex of Primiparous Cows at a Recommended and a Reduced Plane of Nutrition. Journal of Dairy Science, 72, 1441-1449.

[28] Veerkamp, R.F., Oldenbroek, J.K., Van der Gaast, H.J. and Van der Werf, J.H.J. (2000) Genetic Correlation between Days until Start of Luteal Activity and Milk Yield, Energy Balance, and Live Weights. Journal of Dairy Science, 83, 
577-583. http://dx.doi.org/10.3168/jds.S0022-0302(00)74917-4

[29] Berry, D.P., Buckley, F., Dillon, P., Evans, R.D., Rath, M. and Veerkamp, R.F. (2003) Genetic Relationships among Body Condition Score, Body Weight, Milk Yield and Fertility in Dairy Cows. Journal of Dairy Science, 86, 2193-2204. http://dx.doi.org/10.3168/jds.S0022-0302(03)73809-0

[30] Veerkamp, R.F. and Brotherstone, S. (1997) Genetic Correlations between Linear Type Traits, Food Intake, Live Weight and Condition Score in Holstein Friesian Dairy Cattle. Journal of Animal Science, 64, 385-392. http://dx.doi.org/10.1017/S1357729800015976

[31] Berry, D.P., Buckley, F., Dillon, P., Evans, R.D., Rath, M. and Veerkamp, R.F. (2002) Genetic Parameters for Level and Change of Body Condition Score and Body Weight in Dairy Cows. Journal of Dairy Science, 85, 2030-2039. http://dx.doi.org/10.3168/jds.S0022-0302(02)74280-X

[32] Ahlborn, G. and Dempfle, L. (1992) Genetic Parameters for Milk Production and Body Size in New Zealand HolsteinFriesian and Jersey. Livestock Production Science, 31, 205-219. http://dx.doi.org/10.1016/0301-6226(92)90018-Y

[33] Spelman, R. J. and Garrick, D. J. (1997) Effects of Live Weight and Differing Economic Values on Responses to Selection for Milk Fat, Protein, Volume and Live Weight. Journal of Dairy Science, 80, 2557-2562. http://dx.doi.org/10.3168/jds.S0022-0302(97)76211-8

[34] Pérez-Cabal, M.A. and Alenda, R. (2003) Lifetime Profit as an Individual Trait and Prediction of Its Breeding Values in Spanish Holstein Cows. Journal of Dairy Science, 86, 4115-4122. http://dx.doi.org/10.3168/jds.S0022-0302(03)74025-9 